\section{John H. Kessel}

T ohn H. Kessel, a leading scholar of the presidency and party politics, died at age 90 in his Columbus, Ohio home on January 28, 2019, with his beloved wife Margaret (Maggie) at his side.

Professor emeritus of political science at Ohio State University, John was a distinguished scholar of American politics. His published research spanned a wide range of topic areas, including city government, public opinion, legislative politics, campaign strategy, nomination politics, judicial politics, and the presidency. His research made major advances in the understanding of mass political behavior, but his most distinctive contributions were on the presidency. He pioneered in developing and employing quantitative methods for the analysis of the presidency, and he was a leader in the movement to study presidents and their administrations in systematic ways.

John was born in Dayton, Ohio. He went to Purdue University to pursue an engineering degree. But on discovering that he was most interested in history and the social sciences, he transferred to Ohio State University and received his BA degree in 1950.

Having participated in Navy ROTC at both Purdue and Ohio State, he joined the US Navy as an officer and saw action in the Korean War. After his navy service he entered the graduate program in political science at Columbia University, receiving his $\mathrm{PhD}$ in 1958. During his time at Columbia, he returned to Ohio to work on a 1956 gubernatorial campaign. That experience became the fodder for his dissertation research, in which he analyzed that campaign and the strategies of the candidates' organizations.

John's first academic appointment was at Amherst College, where he taught from 1958 to 1961 . He then taught for four years at the University of Washington and five years at Allegheny College, where he was the Arthur E. Braun Professor of Political Science. One highlight of his years at Allegheny was that he served as an undergraduate adviser to John Aldrich and Morris (Mo) Fiorina and helped to launch their careers as distinguished political scientists. In 1970 he returned to Ohio State, where he spent the rest of his career, retiring in 1994 but continuing to teach and to participate in the profession after that time. During his years at Ohio State he served as a visiting professor at the University of Washington and the University of California at San Diego.

John continued to participate in the political process in his early years as a faculty member, and in the 1963-64 academic year he served as a fellow with the Republican National Committee. Meanwhile, he further honed his analytic skills as a social scientist. He was a young scholar at the time that the behavioral revolution was beginning, and he participated actively in that movement. He had never taken a course in statistics, but he worked hard and successfully to become expert in statistical analysis of data. Indeed, in the year after his service with the Republican National Committee he was a member of the executive council of the Inter-University Consortium for Political Research.

John's first book, The Goldwater Coalition (1968), drew on both his close observation of the campaign and his study of political methodology, which was reflected in features such as the first use of Venn diagram analysis to understand the coalitional basis of American political parties. The book is the first comprehensive scholarly report on a presidential campaign. It also set the pattern for his scholarship throughout his career, which combined a rich understanding of the political process with a commitment to rigorous analysis.

His early publications included the first scholarly analysis of public attitudes toward the US Supreme Court and its opinions, the first comparison of voting at presidential, gubernatorial, and congressional levels, and one of the early studies of the role of state delegations in Congress. He also contributed a careful analysis in the 1972 American Political Science Review of the issues involved in the controversy over the extent of issue-based voting.

His next step was a groundbreaking study of the presidential staff. He was the first to interview the presidential staff with structured interviews that allowed quantitative analysis. His 1975 book The Domestic Presidency is a report on his interviews with members of the Domestic Council staff, the White House unit that was drafting much of President Nixon's domestic program. He asked staff members about their own policy preferences, the tasks to which their time was devoted, persons from whom they received and sent messages, and their perceptions of other actors inside and outside the White House. Whereas journalists emphasize the differences among staff members and between them and the President, Kessel showed that their policy views were quite similar. His analysis of interactions among presidential staff was an early version of network analysis in political science, anticipating what has become an important methodological approach in the discipline.

Kessel also was the first to apply content analysis to the State of the Union Messages. His analysis of the messages of Presidents Truman, Eisenhower, Kennedy, and Johnson led to his identification of half a dozen meaningful policy areas. He found substantial differences among presidents in their emphases across these areas. John's factor analysis of those messages led him to reflect on whether the differences represented differences between the two parties, but he concluded that the pattern instead suggested temporal changes. He then extended his study to nomination and electoral politics, with content analysis of 1972 party platforms and campaign speeches plus the subsequent inaugural address and State of the Union Message. That research emphasized how the president's political appeals vary across the political "seasons"-platform writing, campaign rhetoric, and the presidency itself.

His 1980 book, Presidential Campaign Politics, combined analysis of campaign strategy with fresh insights into the reactions of the electorate. He then returned to the study of executive politics with interviews of the Carter and Reagan White House staffs. The interviews enabled him to make comparisons across time as well as to note differences and similarities between the principal staff units, with the core analysis reported in a pair of articles in the American Journal of Political Science.

His 1984 book, Presidential Parties, combined the major report of his analysis of the White House with a parallel study of Congress, and it updated analyses of nomination politics, campaign strategy, and voters' reactions. His examination of voting involved his analysis of the open-ended party and candidate likes and dislikes 
questions in the presidential-year surveys of the American National Election Studies as a basis for measures of the effects of vote predictors in the probit framework. Subsequent book chapters by Kessel in collaboration with his graduate students applied the voter analysis to later elections, with a summing up through the 2000 election in his chapter on "Views of the Voters" in Weisberg and Wilcox, Models of Voting in Presidential Elections (2004).

He was the senior scholar on a National Science Foundation grant to interview county-level leaders of the 1988 presidential campaign organizations, a project which led to major articles in both the American Political Science Review and the American Journal of Political Science. The study showed that these leaders were "true believers" rather than representatives or vote maximizers. Surprisingly, it also found that a third of the Republican county leaders had once been Democrats. The researchers showed that party switches led to increased issue distance between the two parties, the forerunner to our current ideologically polarized parties.

The quality of John's scholarship demonstrated his strong commitment to get things right. He was careful and meticulous in his work, and his research reflected the same integrity that characterized everything he did as an academic and as a person. His reputation for maintaining scholarly standards and for integrity led him to be selected for some of the discipline's most important roles. He was elected to the APSA Council in 1969. He was then appointed as chair of the rules committee for the 1972 APSA Annual Meeting, a position that was especially important because there were heated contests in that year's APSA elections. In 1978-79 he served as president of the Midwest Political Science Association. In that role he navigated the controversy over holding the association's convention in Chicago when Illinois had not ratified the Equal Rights Amendment by conducting a membership survey and using its results to negotiate a compromise between the competing positions. Over the years he held a series of other positions with APSA, the Midwest Political Science Association, and other organizations.

He made a distinctive contribution as a journal editor. When he became editor of the Midwest Journal of Political Science in 1974, he initiated its new title of the American Journal of Political Science, a change that reflected a greater emphasis on rigorous analysis of empirical issues and the journal's nationwide reach. As editor he instituted a section known as "The Workshop," the first methodology-oriented section in a major political science journal. Contributions to that section were later collected into a book edited by John and three later AJPS editors, Theory-Building and Data Analysis in the Social Sciences (1984).

The impact of John's research in moving the study of the presidency forward through more systematic analysis was reinforced by his leadership in the Presidency Research Group. He served as president and vice president of the group, and he was a member of its steering committee for several years. The group later became the organized section on Presidents and Executive Politics within APSA. With George Edwards and Bert Rockman, in 1993 he edited Researching the Presidency: Vital Questions, New Approaches, an important step in consolidating and encouraging research on the presidency that is theoretically well-grounded and methodologically strong.

John's impact on the profession as a whole was paralleled by his impact on the Ohio State University Political Science Department. He joined the department at a time when it was beginning to develop strengths as a home for political science research. He contributed vitally to the effort to continue that development, and his leadership was a key to the department's establishing itself as a leading department with particular strength in American politics. He worked hard to help recruit promising young scholars to the department, and as a mentor he did a great deal to help those scholars to achieve their promise.

John's strong commitment to scholarship was matched by his devotion to teaching. He taught innovative and challenging courses in American politics, and he played a major role in shaping the department's graduate and undergraduate curriculum to reflect new foci in the discipline. He served as a role model in maintaining that full professors had a responsibility to participate in teaching introductory courses. He contributed to teaching in another way, writing books that communicated effectively to both students and scholars. With his coauthors George Cole and Robert Seddig, in 1970 he published Micropolitics: Individual and Group Level Concepts, an innovative text designed to introduce undergraduate students to a structured framework for the analysis of political behavior.

During his time at Ohio State he served as adviser to a long series of PhD students. It is impressive that so many of the graduate students with whom he worked have distinguished themselves in their own careers, and it is equally impressive that they feel such strong ties with John.

For students and colleagues who watched John at the office and kept up with his publications, he seemed like someone who was focused on his work. But hardworking as he was, he was a person with a wide range of interests and activities. He was extraordinarily well read across many fields. It was a pleasure to talk with him about any of those fields, from academic disciplines to baseball. He was an avid gardener and tennis player, and he enjoyed travel a good deal. He was devoted to his family, including his two sons, three grandchildren, and a great granddaughter. Most important was Maggie, whom he married in 1954 and with whom he shared the rest of his life.

\section{- Lawrence Baum, Ohio State University}

- Herbert Weisberg, Ohio State University

\section{Lily Ling}

\section{工} ily Ling, our dear friend and colleague, passed away unexpectedly on October 1, 2018, just as our hopes had gathered momentum that she would recover from a nasty stroke early on in that year. Her work had been recognised and honored, in her absence, at the FTGS (Feminist Theory and Gender Studies) Section's Eminent Scholar panel at the March 2018 annual convention of the International Studies Association. We had hoped for a double celebration of her full recovery and her extraordinary scholarship again at the 2019 ISA annual convention; instead she left us grieving and struggling to reconstruct memories of our association and conversations with her. She always had a lot to say and in all this time without her, we have wondered how she would have responded to different political developments and shape new paradigms to understand the intricacies of global politics and the discipline of International Relations (IR). In this memoriam, we wish to pay tribute to Lily, our thoughtful and generous friend and a scholar extraordinaire.

Lily was a remarkable scholar who challenged epistemic dominance of the West in international relations through a close 
scrutiny of texts, sharp analysis of the links between colonialism and continuing epistemic violence, and developing imaginative alternative frames. Through her critique of mainstream IR, she developed the theory of 'worldism' within international relations, which built on narrative studies, the arts, and alternative accounts of global affairs. Knowledge creation, for her, was a collective enterprise that relied on rereading and drawing from ancient knowledge systems, which had never even found a footnote mention in mainstream IR.

In her oft cited early critique (with Anna Agathangelou; 2004), Lily argued that Westphalian IR "comes to resemble a colonial household... [that] stakes out an establishment of 'civilization' in a space that is already crowded with local traditions of thinking, doing and being..." in the name of creating "order." This is done through "appropriating the knowledge, resources, and labor of racialized, sexualized Others for its own benefit...while announcing itself the sole producer-the father-of our world." This piece arguably laid the foundation of Lily's thinking as it evolved towards developing the concept of worlding. In her paper "Worlds beyond Westphalia: Daoist dialectics and the 'China threat", Lily argued that the threat of China as perceived in the West underscores the pathologies of othering that are so central in the histories of the West's relationship with the Global South and called for challenging this to develop ontological parity between the two. She introduced Daoist dialectics here to show "how we can reframe this issue by revealing the complicities that bind even seemingly intractable opposites, thereby undermining the rationale for violence," through which "we may begin to shift IR/world politics from hegemony to engagement, the 'tragedy' of great power politics to the freedom of discovery and creativity" $(2013,549)$. This move from hegemony to engagement underlined Lily's approach to worldism-it is a relational approach to IR that takes into account the injuries of imperialism but also sees a way forward towards recognising the multiple worlds which we occupy, multiple ways of being and multiple interactions between 'us' and 'them'. This account does not reject Westphalian history of international relations, it rather points to the importance of Westphalia "within us"-how "peoples of India and China...simultaneously contested and embraced the European Enlightenment" (2014, 34). However, Lily took this analysis forward and suggested that Westphalian IR also needs to acknowledge that this nuanced dialectical thinking needs to work both ways to recognise the erstwhile colonised world "within it." Daoist dialectics however, allowed Lily to move beyond the politics of naming and recognition. Through her emphasis on relationality, multiple worlds, Daoist dialectics and "mutual learning" between worlds (ibid., 37) she arrived at worldism, which is underpinned by working towards healing the injuries of the past as we move forward together with our eyes wide open.

This is not an easy argument and approach to put forward. Often this would provoke responses that puzzled, upset and frankly infuriated Lily. She expressed this angst in an email thus, "I find a [n] ... undercurrent of racism in responses to postcolonial work (like mine) that raises pre-Westphalian (that is, non-Western) worldviews and cosmovisions. The charge is that we are reproducing the West vs Non-West divide without investigating what these preWestphalian views are! In other words, these critiques are imposing a Westphalian binary onto pre-Westphalian ways of thinking that are, by definition, not binary. Sigh." (Personal Communication, January 23, 2017).

A second thread in this dialectical journey was Lily's insistence on the importance of the everyday-of 'living dialectically'.
She often used to laugh and say, "we must not just work but play and plot." In her work, though, this approach to the everyday took the form of taking festivals, rituals, foods and clothing (she organised a conference on the politics of fashion, for example) seriouslyas markers of the presence of multiple worlds but also of getting past them through creative and respectful fusion (only she could curate a beautiful dinner for the panel that convened to award her the FTGS Eminent Scholar Award in 2018 at the ISA from her sick bed-it had to be close to the hotel, Chinese, and where everyone could sit together!). In so doing, she built on the feminist challenge to the division between the domestic and the public, while at the same time challenging feminist and other IR scholars to engage with the textures of everyday life as analytical resources but also as play: she noted playfully that the Westphalian World "serves as yang [striding forcefully in public, visibly and imposingly] to Multiple Worlds' yin [acting in private, hidden and silenced]" $(2014,18)$. As Meghana Nayak wrote in her book review, through this playful yet sharp engagement with Westphalian IR, "what will seem like a deficit to some-namely, an analysis of gender that is only briefly situated within certain feminist fields-will be a strength to others who enjoy the process of learning through dialogic engagement" $(2015,357)$. The book that she was working on-which morphed from one to three volumes-was titled Culture and World Politics: Journeys Beyond the West. Lily sent us the introduction to this in which she wrote: "In returning the erased Other to IR, we stem the epistemic violence/epistemicide that the field has normalized for too long."

If her thought processes, analytical approaches, and epistemological challenges were complex, Lily's writing was joyful and superbly creative. Perhaps the book that epitomizes this is Imagining World Politics Sihar \& Shenya, A Fable for Our Times (2014). Shirin remembers that when Lily first broached the idea - she [Shirin] was intrigued but skeptical. Writing 'otherwise' in a highly competitive and judgmental academic work takes courage; Lily always had that. She wrote a fable or a fairy-tale connected to our timeinspired by Indian comic books. We, who had grown up with these comics, would never have found the route through them to writing about world politics, but Lily did. In so doing she created Sihar and Shenya, as symbolic of the big differences of yin and yang-male/ female; self/other-being pulled together through small 'intertwinements' that help constitute a whole. Why did she not write a straightforward academic piece to say this? "Artistic expression helps us to inhabit change while appreciating its disruptive stimulations...aesthetics bridge action with ethics with a state of being. Simply knowing and doing right are not enough, one must also feel it," Lily wrote in the preface to this book (ibid., xxi). In setting herself free from the bonds of academic writing, Lily also sets us free as we read this book-our imagination, as we follow this play, allows us to see how this dialectical approach might operate without compromising on the rigor of the argument.

Lily's Daoist dialectics, especially when she sought to bring together the Indian and Chinese traditions of religious thought, did not always find easy takers. And no doubt, Lily thought that not all thinking was flexible enough to get away from the familiar structuralist intellectual hinterland. As her colleagues and friends, we were intrigued, and skeptical but also excited about the ways in which she would prepare the ground for us to rethink our positions, challenge and provoke our belief systems and scholarly inclinations. Lily was never uncomfortable with 'difference' and had friends-Shirin and Lily often had robust debate about the place of religion and culture 
in our political analysis-with wide ranging views and interests. The fact that she shared such different journeys with both of us, speaks volumes about her capacity to embrace and understand difference, of words, thoughts, ideas and worldviews.

Swati has been deeply inspired by Lily's call to find one's voice through one's roots, and is now looking at cultural and religious exchanges that shaped contemporary India (including rereading of the dialogic traditions of the Upanishads and Advaita Vedanta, the Bhakti-Sufi traditions of building communities and religious/secular identities, and working on a biography of a Belgian Jesuit, Camille Bulcke, who became the most acceptable Ram Katha vachak or story teller in parts of the Hindi-speaking region of north India). It is Lily's inspiring work on Eastern philosophies and traditions that has, in recent times, made her turn to the study of ancient Indian texts and parables to understand the contemporary and now which has poisoned people against their own; which is breeding violence, fear, bigotry and racism. The Upanishadic wisdom in India talks about the tradition of disagreements and dialogue that propelled society towards intellectual challenges and progress in ideas. After all, we cannot live without meaning, and everything ever achieved we owe to this inexplicable evolutionary urge to reach beyond our grasp, do the impossible, know the unknown. Lily also believed in that evolutionary heritage of knowledge that needs to be reclaimed and brought forward as we forge a world of epistemic compassion. She would have approved of looking for answers to contemporary problems in the traditional knowledge systems of the worlds that have merely served as case studies for the high theories coming from the global north. We now have an abundance of theories, even on culture and civilization, all coming from the north, that we continue to test on parts which can be successfully 'culturized' and 'civilized'.

There were many unfinished conversations with Lily which would have taken the shape of collaborative projects, writings, emails, post- or pre-conference musings, perhaps. It is possible that her work will still inspire and enable, amidst others, the discovery of the compassion and kindness of Maitreyi, the future Buddha, who would take form at the time most needed and clear away distracting and destructive emotions. Lily believed that Maitreyi, metaphorically, would help us expand our ideas of time and the globe, save us from the walls we have surrounded ourselves with, the discourses that have limited our imagination in confronting modern challenges. Maybe, IR would not look anything like IR-and we think Lily would celebrate that with us, while reminding us that the task was not yet over until every edifice of understanding non-western world from western knowledge systems was completely dismantled.

We shared a great friendship with Lily; read each other's works, enjoyed gossip, laughed together-often raucously-enjoying eating and shopping together and were at times robustly argumentative! Long-term friendships are built on such intellectual honesty, sense of humor, mutual respect and learning. We miss Lily Ling: her wisdom, compassion, anxieties, frustrations, and above all, her love and friendship will forever stay with us and inspire us in our efforts to be better scholars and above all to be better human beings.

- Swati Parashar, University of Gothenburg - Shirin M. Rai, University of Warwick

\section{Jim March}

Tames G. March, one of the central founders of modern organization theory, passed away on September 27, 2018 at the age of 90, only a month after the passing of his high school sweetheart and wife of 71 years, Jayne D. March. They had four children (Kathryn, Gary, James, and Roderic), two exchange daughters (Jutamaad and Chantal), nine grandchildren, one great-grandchild, and countless friends both here and abroad.

Born in Cleveland, Ohio, and raised in Wisconsin, Jim earned his BA (1949) at the University of Wisconsin, Madison, and his MA (1950) and PhD (1953) at Yale, all in political science. His first academic job was at Carnegie Mellon University, which at the time was called the Carnegie Institute of Technology, where he worked from 1953 to 1964 . He then moved to the University of California, Irvine, where he was professor of psychology and sociology and dean of the School of Social Sciences. In 1970 he accepted an offer from Stanford, where he held appointments in the Departments of Political Science and Sociology, the Graduate School of Business, the Graduate School of Education, and the Hoover Institution. $\mathrm{He}$ remained at Stanford for the rest of his life, going emeritus in 1995 .

Jim was amazingly productive throughout his career. $\mathrm{He}$ wrote or coauthored 22 books and almost 200 articles. It is an underestimation to say that Jim's work has been frequently cited-his Google Scholar number is over 250,0oo (yes, you read that right) and still rising-and its importance has been recognized world-wide. Naturally, therefore, Jim won many awards, honorary degrees, and membership in numerous scholarly academies, including the National Academy of Sciences, the American Academy of Arts and Sciences, the Royal Swedish Academy of Sciences, and the American Philosophical Society.

Intellectually as well as institutionally, Jim's career had two main parts. The first was at Carnegie Mellon, where he worked with Richard Cyert, Herbert Simon, and Harold Guetzkow. During the second part, 1972-1989, Jim worked mainly with Michael Cohen and Johan Olsen. (These collaborations began while Jim was still at UC Irvine.)

His later phase and the corresponding Cohen-March-Olsen work is extremely well-known to political scientists. Their inaugural publication was "A Garbage Can Model of Organizational Decision Making," published in Administrative Science Quarterly in 1972. This paper investigated what they called "organized anarchies," which they defined as organizations marked by problematic preferences, unclear technologies, and fluid participation. The authors argued that such institutions confront fundamental ongoing ambiguities and they tried to explain how these organizations nonetheless solve problems and make choices.

This publication was followed by Leadership and Ambiguity (Cohen and March 1974), which studied how American college presidents do their jobs despite working in institutions that the authors hypothesized were organized anarchies, and Ambiguity and Choice (March and Olsen 1976), which posited that most organizations are influenced by a wide array of factors, including roles, duties, obligations, socially constructed meanings, considerations of legitimacy, and myths.

These early volumes were probably read mostly by organization theorists, but soon their ideas were brought into our discipline by three publications that attracted the attention of many political scientists. The first was March and Olsen's “Organizing 
Political Life" (American Political Science Review 1983), followed swiftly by their even more influential paper "The New Institutionalism" (APSR 1984). March and Olsen then made their summary statement in Rediscovering Institutions (1989). This work created a distinctive branch of the 'new institutionalism' that centered on the ideas of ambiguity and a 'logic of appropriateness' that March and Olsen set in opposition to consequentialist logics.

Elsewhere, we and Ken Shotts have criticized this line of work. But nobody can doubt its impact. Indeed, the Google Scholar citation counts are nothing short of astonishing. In temporal order they are approximately as follows: "A Garbage Can Model" (10,700); Leadership and Ambiguity (3,300); Ambiguity and Choice (6,000); "Organizing Political Life" (90o); "The New Institutionalism" (5,700); and Rediscovering Institutions (12,60o). A remarkable run.

Jim's earlier phase, however-a string of accomplishments when he was a very young scholar-was more remarkable still. Even today, organization theorists agree that the 'Carnegie era,' launched by Simon's Administrative Behavior (1947) and culminating in Cyert and March's A Behavioral Theory of the Firm (1963), was a golden age in the field. What is less well-understood is its ongoing relevance for political science. This is a good time to appreciate Jim's contribution.

Jim played a central role in founding what came to be known as the Carnegie School of organization theory-which, in building and creatively expanding on Simon's seminal concept of bounded rationality, ultimately revolutionized the study of organizations. It brought decision-making to analytic center stage, crafting an approach that relaxed the usual, highly restrictive assumptions of economics and replaced them with concepts and assumptions more consistent with the way human beings actually think and behave.

Two books that he co-authored during this time were watershed achievements. The first was Organizations, written with Herbert Simon and published in 1958. This book set out a logically rigorous decision framework for the study of organizations, introduced and integrated a wide range of topics deemed essential to an understanding of organization decision-making-from uncertainty to learning to conflict-and provided a systematic, propositional inventory of what was then believed to be true about them based on current research. Organizations was a great leap forward for the social science of organization, and it was widely and very quickly recognized-across disciplines, including political science-as a landmark work. The team of March and Simon, although they worked together only for three years, would forever be emblazoned in the minds of scholars and the intellectual history of social science.

The second book, which came out in 1963, was A Behavioral Theory of the Firm, written with Richard Cyert and based on a series of papers the two co-authored during the late 1950 os and early 1960s. In our view, this book was Jim March's greatest scholarly achievement. Organizations is rightly regarded as a landmark, for the reasons we've noted. But it was largely a synthetic exercise, systematizing what was then believed and imposing a more rigorous framing. A Behavioral Theory of the Firm was rooted in the same school of ideas, but it was a hugely creative and ambitious undertaking that targeted the existing economic theory of the firm-which was right at the analytic heart of the discipline of economics-and sought to replace it with a behavioral theory that, in its fundamentals, reflected the realities of human decision-making in organizations. Their aim was to revolutionize scholarly thinking about firms, and thereby revolutionize economics.
A Behavioral Theory was pioneering in developing an entirely new way of thinking about firms. Here we want to emphasize two aspects of their approach that, for us, especially stand out. One is that Cyert and March made politics a central part of their account of how things got done in firms and other complex organizations. Conflicting preferences weren't set aside or treated as second-order phenomena; they were fundamental to firms, impacting the strategies of the various players inside the organization, how information might be tailored and manipulated, and how alliances form. As a political scientist, Jim saw firms fundamentally as political coalitions-a view totally at odds with the mainstream economics of the time-and he brought this perspective into the project with Cyert. (One of Jim's best-known and most influential articles, published in 1962, is "The Business Firm as a Political Coalition.")

The other remarkable feature of A Behavioral Theory of the Firm that we want to highlight is its bold methodological departure from the norm in economics of closed-form modeling. Cyert and March turned to computational modeling (then called simulation) to formalize their verbal theory. Computational modeling was part of the heady brew available at Carnegie Mellon in the 1950s. Herbert Simon and Allen Newell had begun using it in the mid-fifties, but their work focused on psychological processes: problem-solving by a single agent. Even at Carnegie, relatively little computational modeling was being carried out in the social sciences. A Behavioral Theory of the Firm, which was probably the first major book in American social science to use computational modeling as a central tool, changed that forever.

Cyert and March's choice of computational modeling was tightly connected to the underlying nature of their verbal theory. Modeling bounded rationality by itself was hard enough. Incorporating multiple decision makers with conflicting preferences made things vastly more complex-and doing both in an internally consistent way was then well beyond the capacity of closed-form modeling to handle. Cyert and March realized that computational modeling - a radical departure from the discipline's methodological norm-was a solution to this tractability problem. This may seem obvious today. It wasn't at all obvious 55 years ago. Simulation was virtually unknown in political science at that time, and in economics the situation was actually worse-for computational modeling was considered deviant behavior, to be practiced only at night, underground. Cyert and March not only did what they needed to do in order to formalize their theory. They also showed intellectual courage in refusing to go along with the mainstream. This is what contributions are made of.

A Behavioral Theory of the Firm was an astonishingly complete, coherent, and creative package. Some people think that it should have earned its authors the Nobel Prize in economics. As Richard Nelson and Sidney Winter pointed out in their equally important book, An Evolutionary Theory of Economic Change (1982), Cyert and March presented not just a critique of orthodox economic theory but also a positive alternative, built on ideas about what real humans-boundedly rational but clever-can accomplish, especially collectively, i.e., organizationally, as Simon $(1947,79)$ had argued before them.

Unfortunately, A Behavioral Theory has had little impact on the theoretical and methodological approaches of mainstream economists, who have largely failed to take advantage of Cyert and March's pioneering ideas. The profound potential of A Behavioral Theory of the Firm has yet to be tapped and the magnitude of its contribution has yet to be fully appreciated. Hopefully, that will 
change as time goes on-and not just in economics, but also in political science. A Behavioral Theory is as relevant today for the study of political institutions as it was in 1963. Its central premise-that complex organizations are political coalitions populated by boundedly rational human beings-holds for public agencies as much as it does for private firms. And all of the key components of ABT's verbal theory-quasi-resolution of conflict, uncertainty avoidance, problemistic search, and organizational learning-generate plausible hypotheses about governmental bureaucracies.

Finally, A Behavioral Theory's methodological innovation, computational modeling, remains extremely useful for political scientists, especially for scholars ambitious enough to construct models whose agents have both conflicting preferences and cognitive limitations. Of course, one could rely only on analytical models if one dropped bounded rationality and focused on intra-organizational conflict, as in standard principal-agent models and similar theories deployed in the flourishing field of organizational economics.

But here Jim March would give no ground. Although he would immediately agree that studying intra-organizational conflict is vital, the above trade-off imposes too great a cost in one of his key scientific values: being true to the phenomena. Humans, he would say, are often sensible and sometimes foolish. What we clearly aren't is completely rational. That's not even a good approximation of the complex problems faced by both firms and agencies. We agree.

Jim March was primarily a theorist, but he was also committed to studying the everyday lives of real people in real organizations. That's a powerful combination for basic as well as applied social science.

Because Jim was such an important and complex scholar, we have said a good deal about his research. But we also want to reflect on his personal qualities. At Stanford, we were fortunate enough to have Jim as a colleague for many years. We can testify, based on firsthand experience, that he was a truly remarkable guy. On campus, he was known and valued not only for his influential scholarship, but also for his performance as a charismatic, enlightening, and outside-the box teacher of Stanford students at all levels: undergraduates, students in professional degree programs, and doctoral students. He taught them about organizational leadership, for example, not in the usual textbook ways, but by using Don Quixote and War and Peace. He was a phenomenon, and his classrooms were filled. He was known for committing to memory the faces and names of his students in large lecture classes so that he could call on them personally, by name. He regularly kept boxes of (cheap) wine in his office to encourage grad students to stop by for informal chats, idea-sharing, and fun. He was friendly, down-to-earth, self-effacing, mild-mannered, and proud of his Midwest roots. $\mathrm{He}$ could speak with great eloquence, but often he didn't talk at alland when he did, he didn't talk about himself. He was interested in other people and wanted to hear their stories. His graciousness and warmth were experienced by many people on campus.

Finally, we should note that Jim was more than a social scientist. He was also a serious poet. Readers might be surprised to learn that he published 11 books of poetry. And he could read poems beautifully. Many years ago, one of us had the pleasure of hearing Jim recite Yeats' "Easter, 1916" in a class we co-taught. Listening to him say "A terrible beauty is born" in his own special way-with meaning and depth-made the Irish struggle for independence come alive.

A wordsmith to the end, Jim March deserves the last word. There are many to choose from, but we thought we'd go with the shortest poem in his book Slow Learner (1985). A few simple words reveal his wisdom and humanity:

\author{
"Love \\ Makes life better, \\ But not easier." \\ - Jonathan Bender, Stanford University \\ -Terry M. Moe, Stanford University
}

\section{Thomas A. Rusch}

T homas A. Rusch, professor emeritus of political science, died on February 12, 2019 at the age of 99 in Paso Robles, California, where he had moved after he retired from California State University, Los Angeles. He taught at the university from 1959 to 1984 .

Tom was a 1941 history BA from the University of Wisconsin. During World War II he was a conscientious objector, stationed at camps for conscientious objectors in North Dakota and Glendora. After the war, he resumed his education at the University of California, Los Angeles, where he received his MA in political science in 1949. He taught at the University of Kentucky for two years and then returned for his $\mathrm{PhD}$ at the University of Chicago, where he specialized in comparative politics and international relations. He received his $\mathrm{PhD}$ in 1955 . His area of the world was South Asia, and Tom consulted and ran institutes on South Asia throughout his career.

While at the University of Chicago, he was a research assistant at the Center for the Study of American Foreign and Military Policy. He also had a Ford Foundation Fellowship in India for 18 months in 1953 and 1954. In 1955, he was the staff director for the Human Relations Area Files, subcontracted to Chicago from Yale. He was a research consultant for the Modern India Project at the Institute of East Asiatic Studies at the University of California, Berkeley, in his final graduate year, 1954-55.

Once he received his $\mathrm{PhD}$, he spent the first year continuing at the Modern India Project at UC Berkeley as a Junior Research Political Scientist. He was the program officer for South Asia for the Asia Foundation in San Francisco from 1956 to 1958. He then spent the 1958-59 year as an instructor at Oakland City College.

He joined Cal State LA in 1959 and directed an Institute of Asian and African Studies for the campus from 1960 to 1963 . He chaired a committee on study abroad for the campus from 1962 to 1964 and was a member of the Chancellor's Statewide Advisory Committee on International Programs during that period. He did research in India on several occasions with campus and external support. $\mathrm{He}$ studied Hindi one summer at the University of Washington with NDEA support.

He published papers in the Journal of Asian Studies, the Political Science Review (India), and the Journal of Politics, plus a book chapter on political leadership in India, all during 1950 to $1974 . \mathrm{He}$ presented papers at a variety of academic conferences, on topics ranging from the opposition in the Indian parliament, to the confrontation between India and Pakistan, the Gandhian approach to international relations, the politics of violence and non-violence, and even "Solar Energy vs. Nuclear Power," the latter before a panel dealing with the prospect of India becoming a nuclear power. 
At Cal State LA, he served on committees in the department and the university. At the university level, most of his appointments dealt with studying abroad. In the department, he taught a variety of courses on comparative politics and international relations, in addition to courses specifically on South Asia and India. He was known for the thoroughness of his preparation of graduate students who went on for the $\mathrm{PhD}$.

Tom lived in Pasadena, where he raised his family, later moving to Silver Lake and Camarillo in southern California before going to Paso Robles in 1988. While retired, he continued his interests in India, history, and politics, becoming a tireless worker for the local Democratic Party and liberal causes. He was a strong supporter of environmental issues and a lifelong believer in non-violence. He had numerous plans for the future even just before his death, two months shy of his 1ooth birthday, on February 12, 2019. He leaves his wife Ruth, daughters Deena Rusch, Pamela Seine, and Miriam Rusch (David); grandson Aidan; former wife Dorothy Rusch; and a beloved dog, Toby.

\section{-J. Theodore Anagnoson, California State University, Los Angeles}

